\title{
特集/レーザーによる計測と病態解明への応用
}

\section{細動脈の自発的周期的血管運動と レーザードップラー血流計測 \\ Spontaneous rhythmic vasomotion of arterioles and laser Doppler flowmetry}

南山 求, 中野 厚史

国立循環器病センター研究所脈管生理部

\author{
Motomu MINAMIYAMA and Atsushi NAKANO \\ Department of Vascular Physiology, National Cardiovascular Center \\ Research Institute \\ Fujishirodai $5-7-1$, Suita, Osaka 565
}

\begin{abstract}
要 旨
レーザードップラー血流計測（LDF）により測定される血流变動（flow motion）は血管 運動（vasomotion）による上言われているが，細動脈の口径を直接計測し比較した報告は少 ない。本研究ではウサギ耳介皮侮血流(SBF) をLDFによって求め, この測定値と同期をとっ て，生体顕微鏡下で耳介㝕（REC）内の細動脈の内径 (ID) お上び赤血球速度 (RBCV) を も測定した。REC内で観察される血管運動は比較的高い周波数を示すものと低い周波数を示 すものとに区別できた。 REC 内の細動脈の血流量（FR）をID よよびRBCV から計算し， SBFとの間で相互相関解析を行った。FR および SBFが比較的高い周波数で変動するとき, 両者の間では明瞭な位相の一致は認められなかった。低い周波数で大きな振幅の血流变動が測 定されるときはFR 直接計測して SBF と比較することにより，血管運動を周波数执よび振幅をよりどころに，局 所的なものと耳介全体を支配する目律神経活動によるものとに区別できることが示唆できた。 キーワード：レーザードップラ一血流計測、ウサギ耳介㥕法, 細動脈血管運動, 血流变動
\end{abstract}

\begin{abstract}
Synchronous measurements of fluctuations of ear skin blood flow (SBF) and blood flow rate (FR) in a single arteriole in a rabbit ear chamber (REC) has been studied by utilizing laser Doppler flowmetry and a newly developed method, respectively. FR's were calculated with inside diameters (ID) and red blood cell velocities $(\mathrm{RBCV})$ in arterioles in the REC. ID and RBCV were simultaneously measured by a video image analysis system and a dual - photometric method with a cross correlation analysis, respectively. Patterns of the flow motion of SBF and FR during vasomotion were classified into the following two oscillations types. One type was relative high frequency and small amplitude oscillations. Another type was low
\end{abstract}


frequency and large amplitude oscillations. Low frequency oscillations superimposed on high frequency oscillations. When we observed high frequency oscillations, there was a poor correlation between SBF and FR. When low frequency oscillations of FR was only showed, we observed a clear correlation between SBF and FR. We suggest that high frequency oscillations to be local non - neurogenic vasomotion and low frequency oscillations to be pure neurogenic origin.

Keywords : laser Doppler flowmetry, rabbit ear chamber, vasomotion, flow motion

\section{1.はじめに}

生体の微小血管を顕微鏡下で観察すると自然発生的で 律動的な収縮搪張運動が見られる”。この口径変化を血 管運動（vasomotion）よ言い，こ机は微小血管内の血 流が相動的であることの一因ともなる。近年、レーザー ドップラー血流計测法（LDF：laser Doppler flowmetry）によって簡便かつ非侵䈍的に微小循環レ ベルでの血流測定が行われ，皮落の血流变動（flow motion）のパターンを病態解析に応用した報告がみら れるようになった。例えば，末梢動脈閉塞疾患")，心不

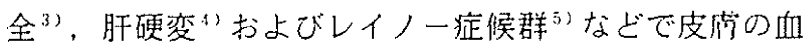
流動態をLDFにより把握する試みが行われている。 LDF の出力結果に仮定を設けて血流量の絶対值を求め る方法 “功考案されたり，血流の生理的ゼロレベル”在 求めたりされているが，LDF の出力パターンを相対値 のままで比較解析することの意莪は变わらない。また， LDF の出力結果を他の原理に基づいた血流計测方法と 比較した報告 ${ }^{8.91}$ では測定結果の妥当性が示されている。 特に，ヒ卜爪床において LDF と毛細血管内の赤血球速 度を比較した報告ばでは血管運動上の関係が解析され ている。しかし，同一組織でLDF の測定結果と細動脈 の口径変化（vasomotion）を直接比較唡討した報告は 少ない。皮荷の細動脈を生体顕微鏡下で直接観察する方 法の1つにはウサギ耳空 (Rabbit Ear Chamber, REC）法”があり，REC内に再生した血管床での血 管運動について報告12.13) されている。本研究では生体 顕微鏡下で細動脈の血流量を求めるために内径（ID） と赤血球速度（RBCV）の同期をとって測定する方法 を新たに試作した。この方法を応用してREC内の細動 脈血流量（FR）㧍よび LDFによって得られる耳介皮

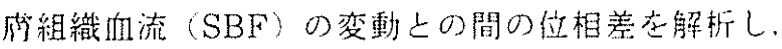
血管通動の発現機序を明らかにすることを目的とした。

\section{2. 実験方法}

\section{1) ウサギ耳空法}

実験には $2.5 \mathrm{~kg}$ から $3.3 \mathrm{~kg}$ 雄ウサギを用いた。 Ahernの方法を改良した浅野ら”の方法に従って $\mathrm{REC}$ を装着し, 施術後 1 力月から 4 力月経過した REC 内の再生組織の微小血管（図1) を観察記録に用 いた。

意識下のウサギをステンレス製固定器に入㞦，顕微鏡 (Nikon OPTIPHOTO - 2) のステージ上に耳介を固

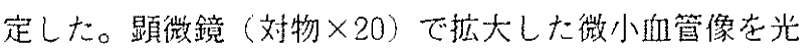
路の途中で 2 分割し，一方ではREC 内の微小血管像を TVカメラ (Hamamatsu Photonics C2400) で撮影 した。このとき，後述のIDサンプリングのために血管 走行が $\mathrm{T} V$ 走査線之平行あるいは垂直になるように鏡筒 を回転させた（図 $2 A$ ）。微小血管のビデオ画像はトリ ガータイマー上共にビデオテープレコーダ(Sony VO 2960 A）に収録さ机る。画像上のトリガータイマーは後 述のアナログデータレコーダ（Teac R-81）を制御す るパーソナルコンピュータ（NEC PC - 9801VM 2) の内蔵時計在利用し(N88BASIC), 画面上にタイマー を表示して微小衈管像に上書きするスーパーインポーズ ボード（NEC PC-9801-25）により得た。

他方の光路では細動脈内の RBCV を測定するために， 顕微鏡の焦点面上に 1 対の光ファイバーの先端面を圈き

(図3A)，2 個のフォトダイオード (Hamamatsu Photonics S1336）の受光面に導き赤血球がセンサー 面を通過する際の輝度变化在得た。こ㣗らの血管中心軸 上の上流側掞よび下流側の光電信号は上述コンピュータ が CMT インターフェースボード（NEC PC - 9801 13）から出力するトリガータイマー信号と共にアナログ データレコータにに収録さ机る。

2) 耳介皮虂組織血流測定

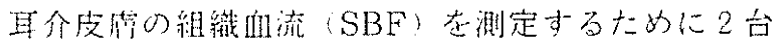
の半導体レーザー式組織血流計〈Biomedical Science 


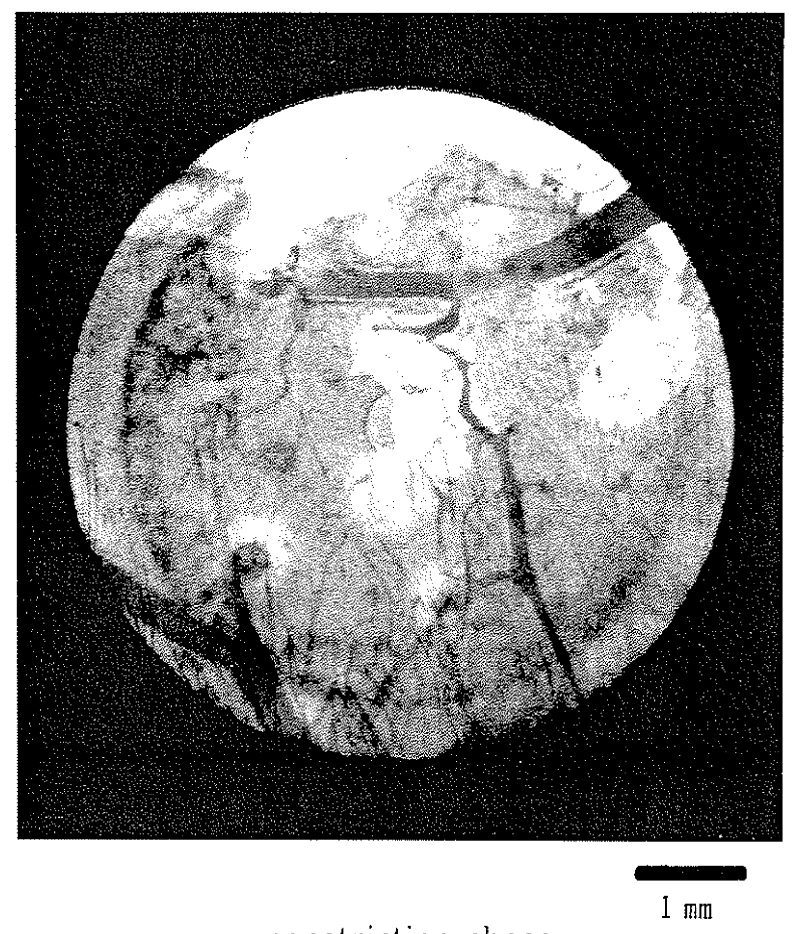

constriction phase

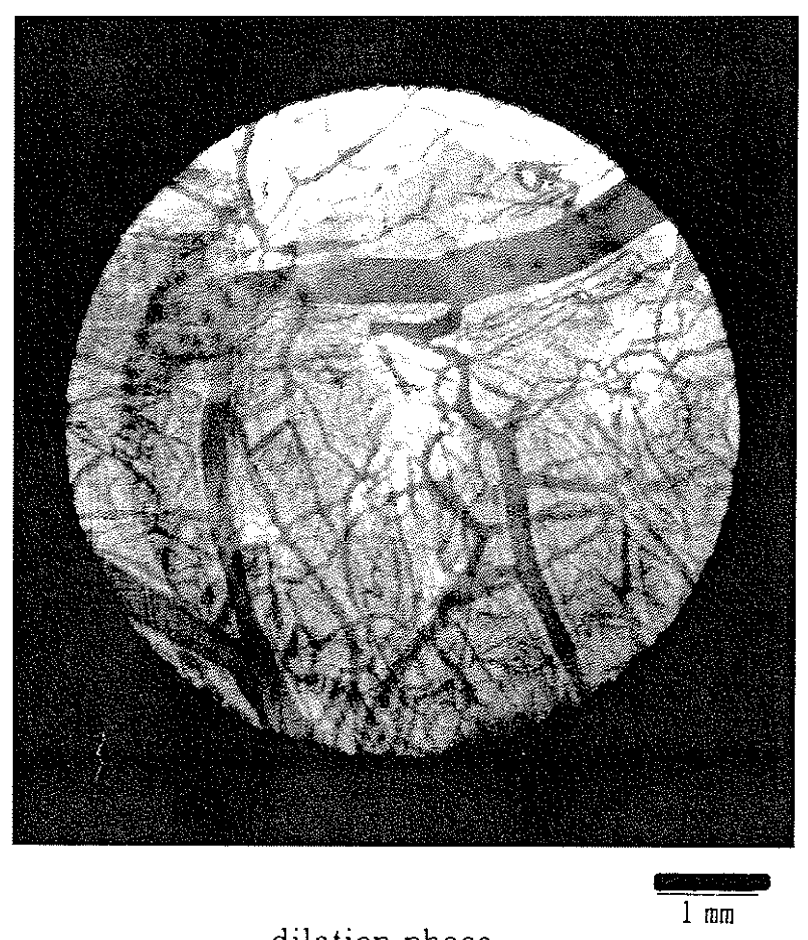

dilation phase

Fig. 1 Microvascular bed in a rabbit ear chamber (REC) during vasomotion.

A

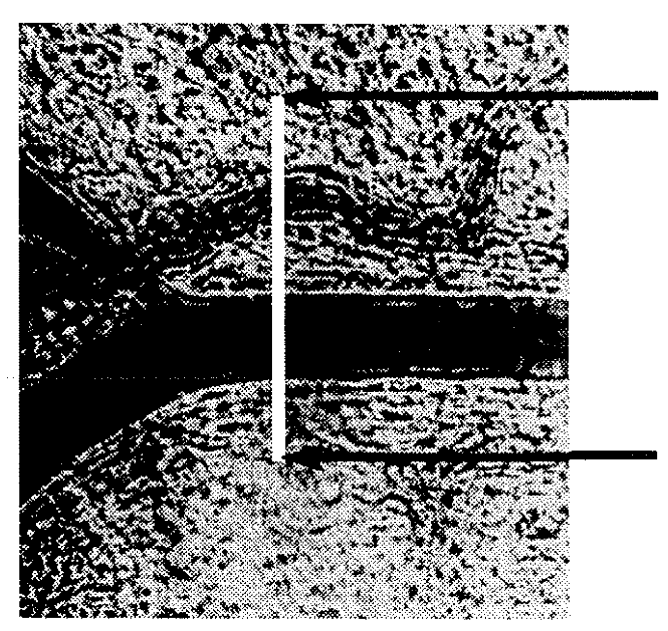

B

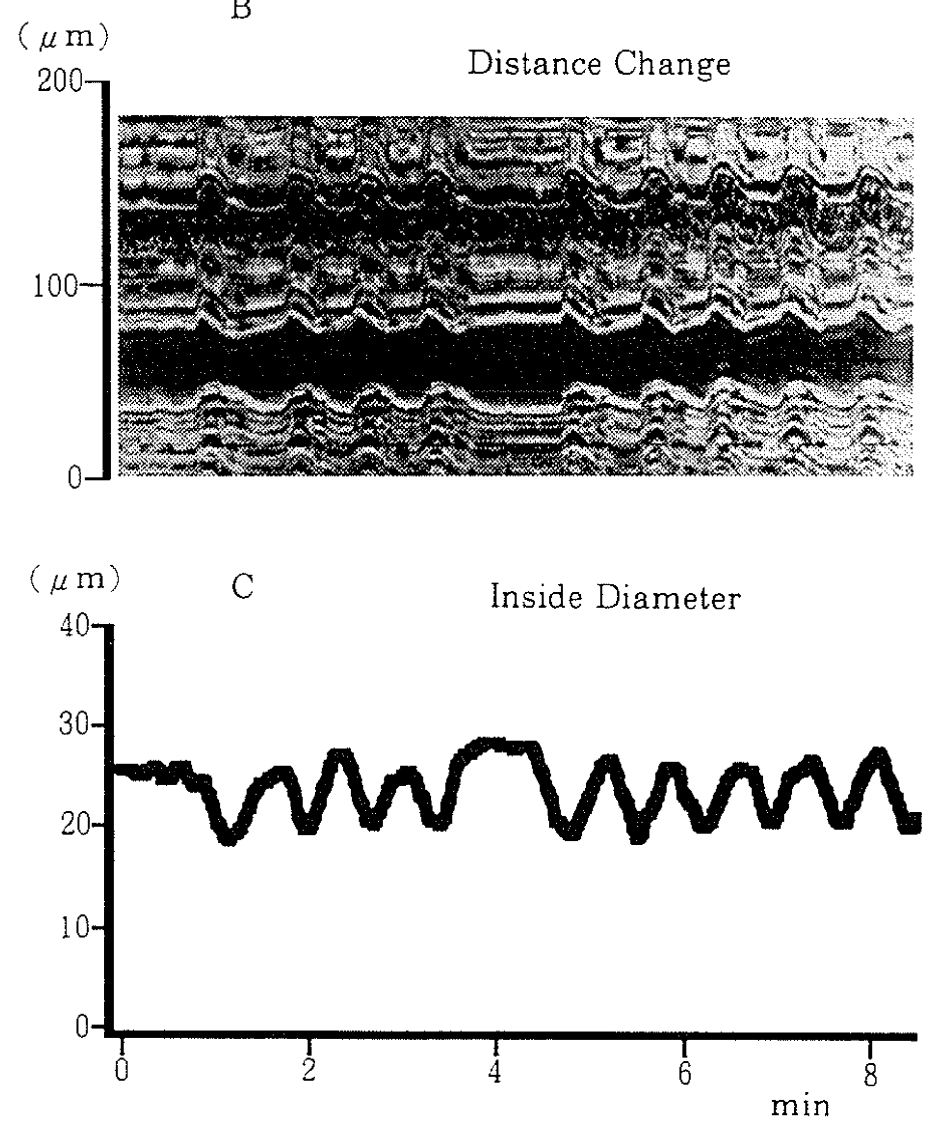

Fig. 2 A : An example of a sampling site for measuring inside diameter of an arteriole in a digitized image. B : Time-series of intensity profiles reconstructed from consecutive video frames with a sampling frequency of $1 \mathrm{~Hz} . \mathrm{C}$ : Temporal changes in inside diameter of an arteriole by an automatic wall-surface-tracing procedure. 
A

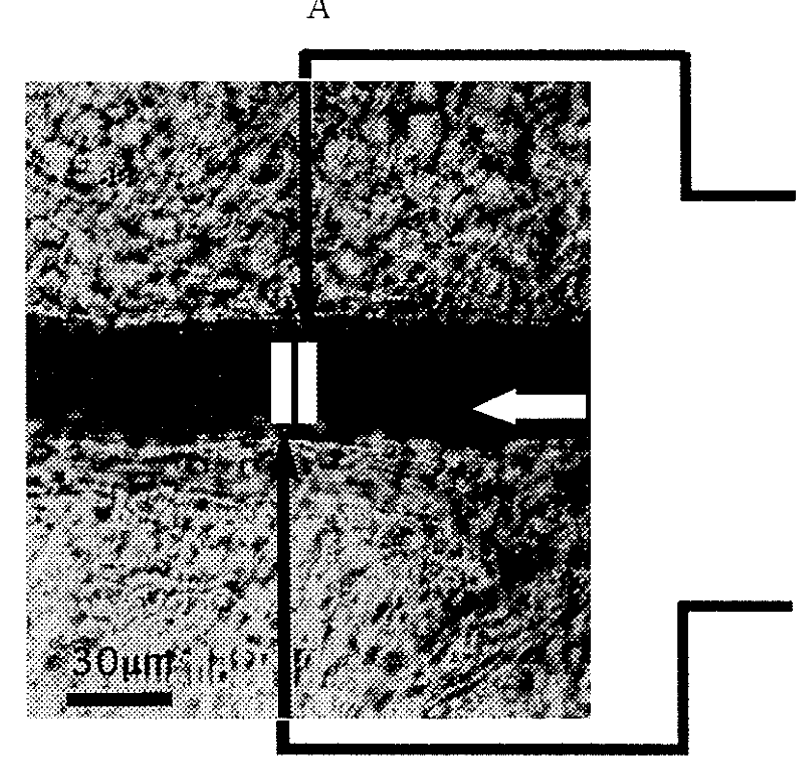

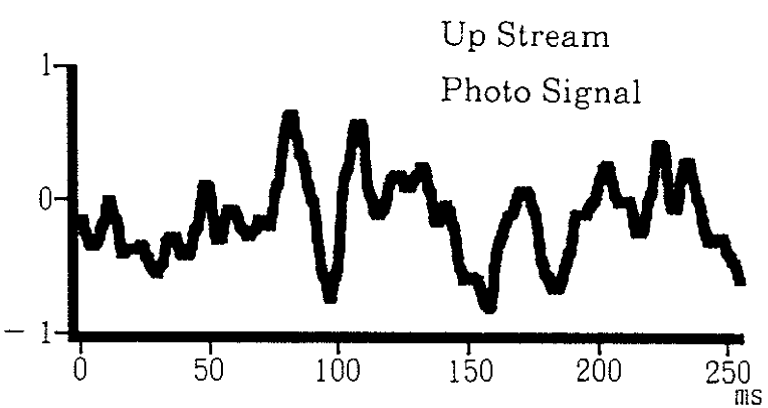

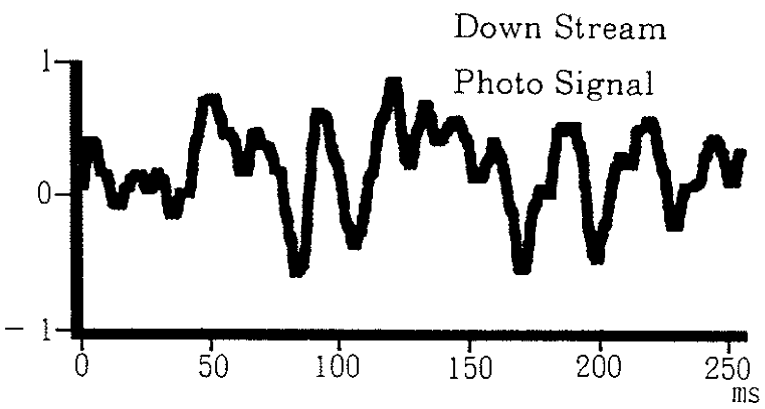

Fig. 3 A : An example of sampling sites for measuring red blood cell velocity in an arteriole in a video image by a dual-slit photometric method. B: Temporal changes in a pair of photosignals of two light detectors. C : A results of a cross-correlation analysis. A peak indicates a time delay of passages of the red blood cells.

LBF－四）を用いた。計測結果に対する信頼性を增す ために1基のレーザー光源を 2 台の LDFに分割して用 いた。耳介の同側部位での測定では2 基のセンサーを数 mm以内に近接して REC 装着部位より中枢側に約 $3 \mathrm{~cm}$ 離 れた位置に装着した。これらの血流信号は上述のトリ ガータイマー信号および光電信号と同時にアナログデー タレコーダに収録される。

3）微小血管径計測

ビデオ再生画像を参照して測定するシーンを選びトリ ガータイマーの表示に従ってデジタル化した微小血管像 の輝度分布のサンプリングを開始した。ビデオ画像のデ ジタル化とサンプリングはリアルタイム画像改善装圈 (Hamamatsu Photonics DVS - 3000) をテクニカル コンピュータ (Teac PS - 9816) で制御することによ り行った。サンプリング周期はテクニカルコンピュー夕 の内藏時計を利用した割り込み分岐（HPBASIC）で
$1 \mathrm{~Hz}$ とした。このサンプリングの間, ビデオテープレコー ダは再生状態を継続した。1度に行うサンプリングは 512回までとし，画質改善装置からコンピュータに取り 込んだ輝度分布の時系列デー夕はハードディスク装置 (Teac PS - 9301DS)に記録した。

ディスク装置から読みだした輝度データはビデオフ レームメモリ (Hamamatsu Photonics C 1900) に 順次転送し，TVモニター（Mitsubishi JUM - 1481 A）に表示した。モ二ター上ではY軸方向の輝度変化は ある時刻の輝度分布を， $\mathrm{T}$ 軸方向は輝度分布の時間経過 を表す二次元画像（再構築画像と呼ぶ）を構築した（図 2 B)。この再構築画像の壁内面索軸方向にトレース することによりIDの变化を求めた（図 2 C)。ソフト ウェア（HP BASIC）に上る自動トレース法"“は概述 済みなので、ここでは省略する。

しかし、このトレー久法は再構筑画像に执いて衈管内 

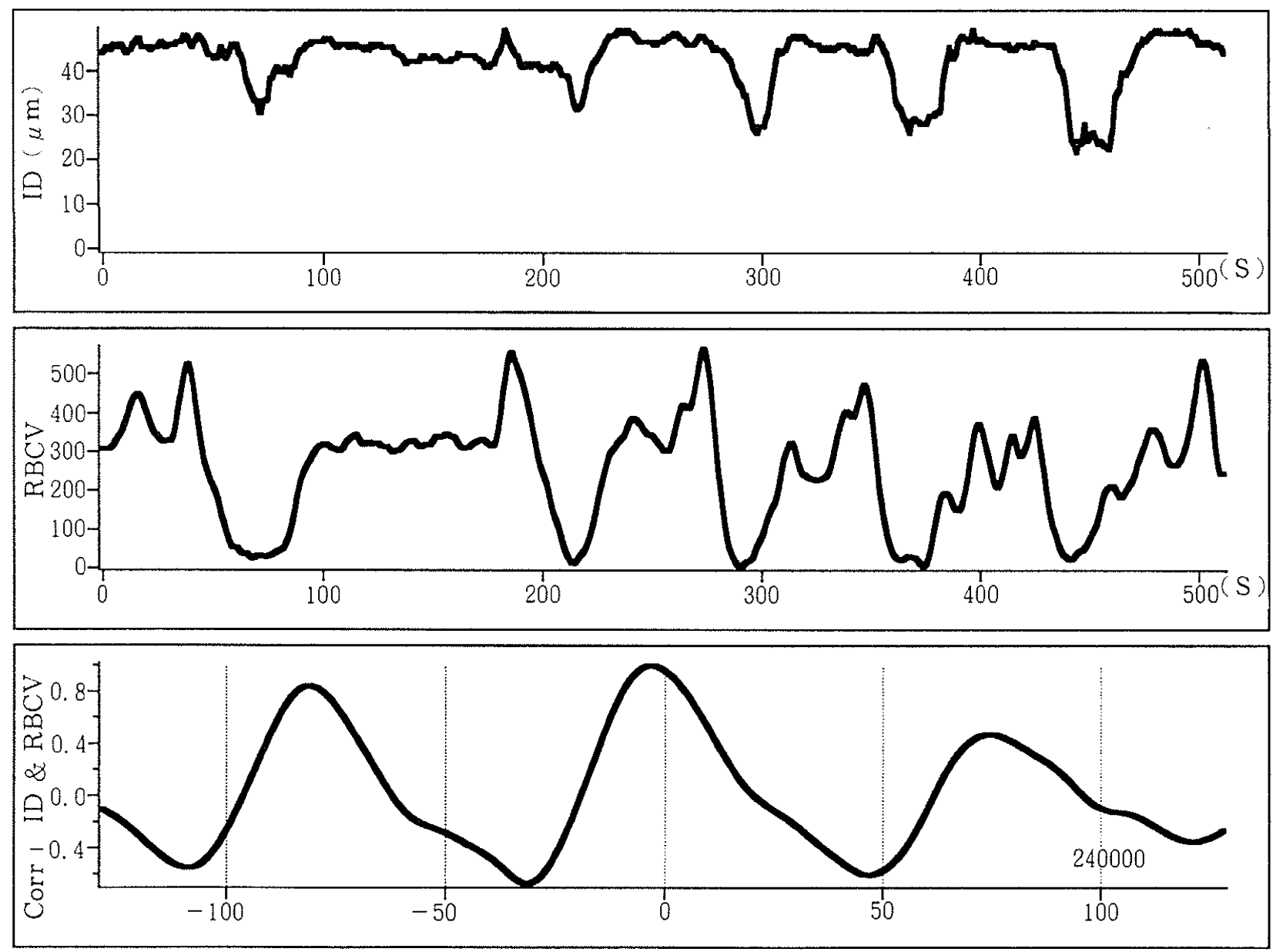

Fig. 4 Spontaneous rhythmic changes in inside diameter (ID) of an arteriole in a REC. Red blood cell velocity (RBCV) in the arteriole comes to rest at the constriction phase of ID. This frequency is 0.5 cycles $/ \mathrm{min}$. There is a clear cross-correlation between ID and RBCV.

の赤血球柱㧍よび辺緣血浆層が認めら机ることを前提と しているので，REC内の血液が血管運動に上って消失 すると計测不能となる。そこでTVモニター上で用手的 に壁内面の位置を決めるための編集システムを試作した。 前もって自動トレース法により得られた誤差を含んだ測 定結果と再構筑画像をビデオフレームメモリ一上で合成 し，さらに，画像改善装置で 4 倍に㹡大表示した。同時 にコンピュータのモニター上に表示した輝度分布を参照 して血管壁面を視覚的に決めた。この操作では合成画像 上およびコンピュータのモニター上とで同時に等距離を 移動するカーソルをソフトウェアに上り実現し，一画素 単位でIDが求められるようにした。

\section{4 ）赤血球速度計測および組織血流計測デー夕処理}

パーソナルコンピュータの CMT インターフェースを 介してアナログデータレコーダに記録さ㧈たトリガータ イマーを読子出して衈管内径の测定結果之同期老取った。 上述の1対の光ファイバーの光電信号拉上び2古の LDF 出力信咢考再生した。こ执的のチャンネルの
データを外部サンプリングクロック（Wavetek 178） を用いたA /D变換器 (Teac PS-9030) でデジタル 化しコンピュータ (Hewlett Packard 319C+) を介 してハードディスク装置（Hewlett Packard 7963B） に再記録した。デジタル化したデータについて以下の演 算を行った。細動脈内の RBCV を求めるために, 1024 デー夕(時間長125msあるいは250ms, 図 3 B ). の相互相 関関数（図 3 C）をFFT 演算ボード（Ariel FFT523） を内蔵したテクニカルコンピュータで求め, 赤血球がセ ンサー間を通過する時間差を測定した。この時間差とセ ンサー間の距離から RBCV が得られる。

LDF 出力信号では光電信号之同時刻の同じ時間長の データについての平均値を計算した。さらに1秒每に 行ったID 計測結果と同期をとるために，ID 計測時前 後の RBCV 扝よび SBFのデータから1秒每の平均值 (512個のデー夕)を求めた。

\section{5) データ解析}

計測したID. RBCV およびSBFのデー夕はそ机ぞ 

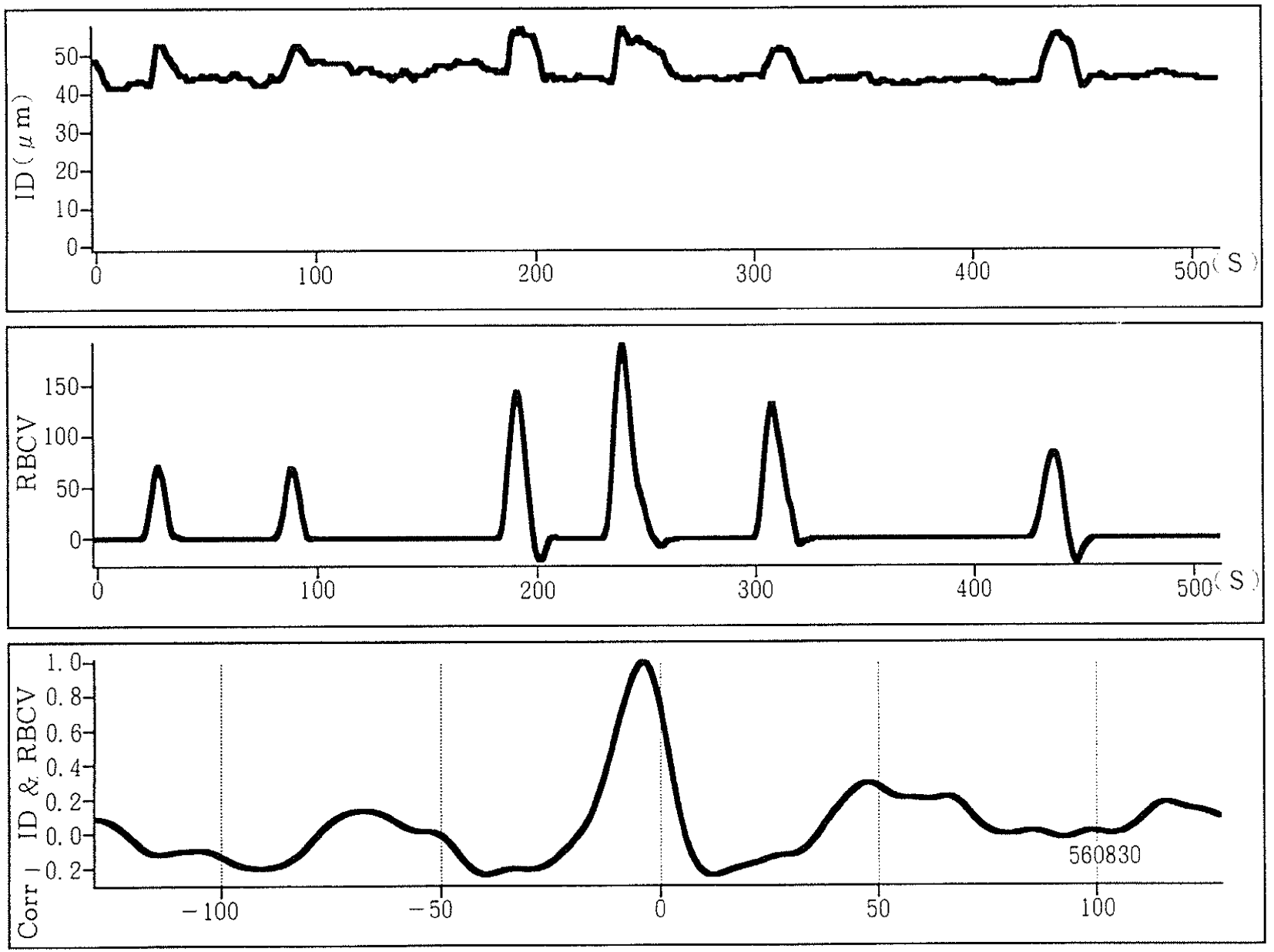

Fig. 5 Spontaneous rhythmic changes in inside diameter (ID) of an arteriole in a REC.

Changes in red blood cell velocity ( $R B C V$ ) in the arteriole is intermittent. This frequency is 0.5 cycles $/ \mathrm{min}$. There is a clear cross-correlation between ID and RBCV.

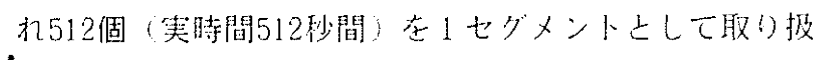
うこととし，全てのデータはパーソナルコンピュータに RS - 232Cインターフェース在介して転送し、表計算ソ フト (Microsoft Excel および Wave Metrics Igor) により解析した。2ケ所同時記録したLDF 出力を比較 し, 出力波形がはぼ相似である実験時に任意の1方の出 力をSBFとした。この SBFと比較するために細動脈の $\mathrm{FR}$ を以下の式を用いて算出しだら。

$\mathrm{FR}=\pi / 4 \times \mathrm{ID}^{2} \times \mathrm{RBCV} / 1.6$

この際, RBCVのノイズ成分除去のために7ポイン トの移動平均演算を行った。 REC内のID R R R と の間，および FRと SBFとの間で相互相関関数解析を 行い, 各データ間の時間的位相差について検討した。

\section{3. 結 果}

1) ウサギ耳介慾内の血管運動と赤血球速度变化

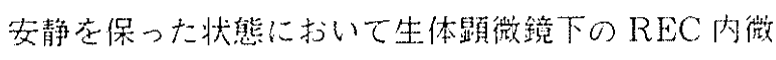

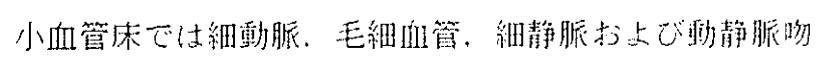

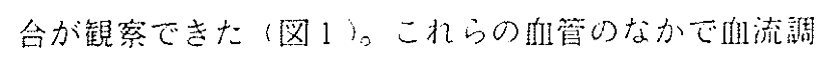

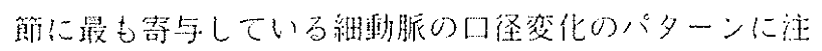
目して計測結果劣分類し解析した。

REC 内の血流がほぼ保たれていて相動的な細動脈の 収蓿が観察された例を図 4 に示す。この血管の収縮時に は血流は途絶え，REC内的血液が消失した。この例 ではID およびRBCV の間の相互相関関数を求めると ID の変化が RBCVよりも遅れていた。REC内の血液 がほとんよ゙無い時間が相対的に長く，間欠的に㿼流が生 じる例を示す(図 5 )。このときには細動脈内の $\mathrm{RBCV}$ が急激に增加した後, 少し荤れて ID が增加することが 観察された。ID执よびRBCVの間の相互相関関数を 求める上非常に良い相関を認め, ID の变化が RBCV上 りも約 4 秒遅れていた（図 5 ）。これらの血管運動の周 波数は約 0.5 cycles $/ \min$ であった。図6では，振䒇が 小さく比較的高い周波数 ( 4 cycles $/ \mathrm{min}$ ) の回管運動 に振幅が大きく低い周波数の仍管連動が重鼠している例 を示す。この例では振幅の大きい上さに而流が途栬える。

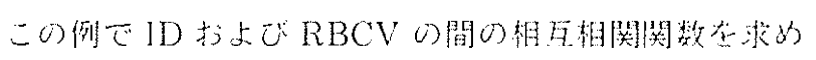
万と。上迅の例上は琵なり RBCVの变化が ID上りも 

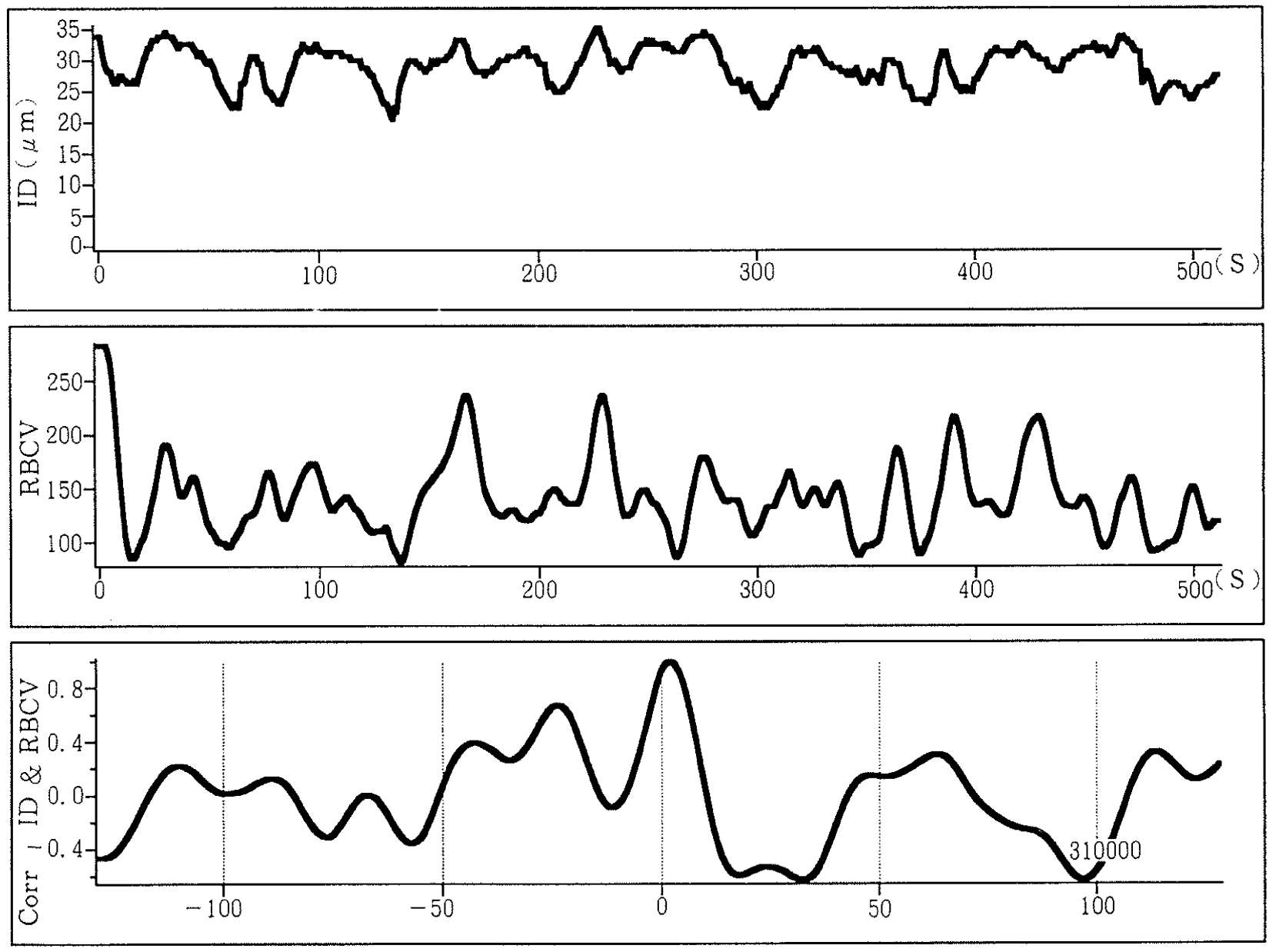

Fig. 6 Spontaneous rhythmic changes in inside diameter (ID) of an arteriole in a REC. ID fluctuates relatively high frequency ( 4 cycles/min). Red blood cell velocity (RBCV) in the arteriole comes to zero at the larger amplitude phase of ID changes. This frequency is 0.5 cycles $/ \mathrm{min}$. There is a clear cross-correlation between ID and RBCV.

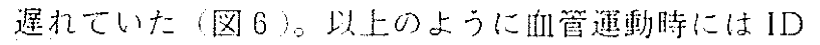
よRBCVの間で高い相互相関が認められた。細動脈に 助管運動が認められず，血液がほぼ一定に流れているよ うに観察される例について RBCV を求めると，比較的 高い周波数（3 cycles $/ \mathrm{min}$ ) で血流が相動的に变動し ていることが示された（図７）。

\section{2) ウサギ耳介兹内の血流变化亡耳介皮膚組織血流}

上述の REC 内の緗動脈のID および RBCV をもと に計算した FR を REC 内全体の䢐流变化を代表してい ると仮定した。 REC内のFRが平均的に高く保た机る 之き，その相動的成分について SBF との間で相互相関 関数を求內, 時間的位相差について調べた。図 8 に示す

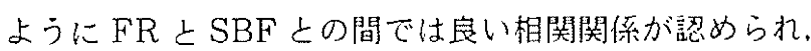
その時間差は約 6 秒間であった。 REC 内の血液が相対 的に長く消失していて，闒火的に血流があるとき。 SBFの变動の中にFRのピーク上一致する波形が諗か

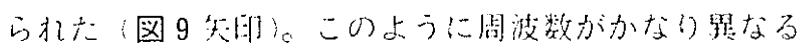

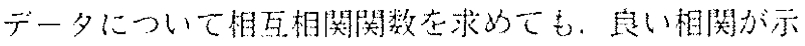

さ㧈る。しかし，FR拉よび $\mathrm{SBF}$ が同样な周波数で变 動しているように見える例であっても，相互相関関数の ピークが時間差ゼロ付近に認められないこともあった (図10)。

\section{4. 考案}

REC内の血管運動には小さい振幅で比較的高い周波 数のものと大きな振幅で低い周波数のが区別され，その 周波数はそ扟ぞれ約 4 cycles/min扩よび0. 5 cycles／ minであった。この結果は浅野ら ${ }^{16)}$ が Microphotoelectric Plethysmographyにより計測した結果とほぼ 一致する。

$\mathrm{REC}$ 内の細動脈に血管運動が出現するとき，その中 の RBCV も变動し，雨者の間には良い相関が認められ た。低い周波数の例(図4，5)では折管の収縮相に REC内の血使が消失していた。このように血液が消失

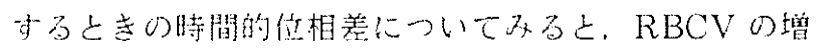
加が问拡大に先行することが観察さ扎た。こ扎は海 

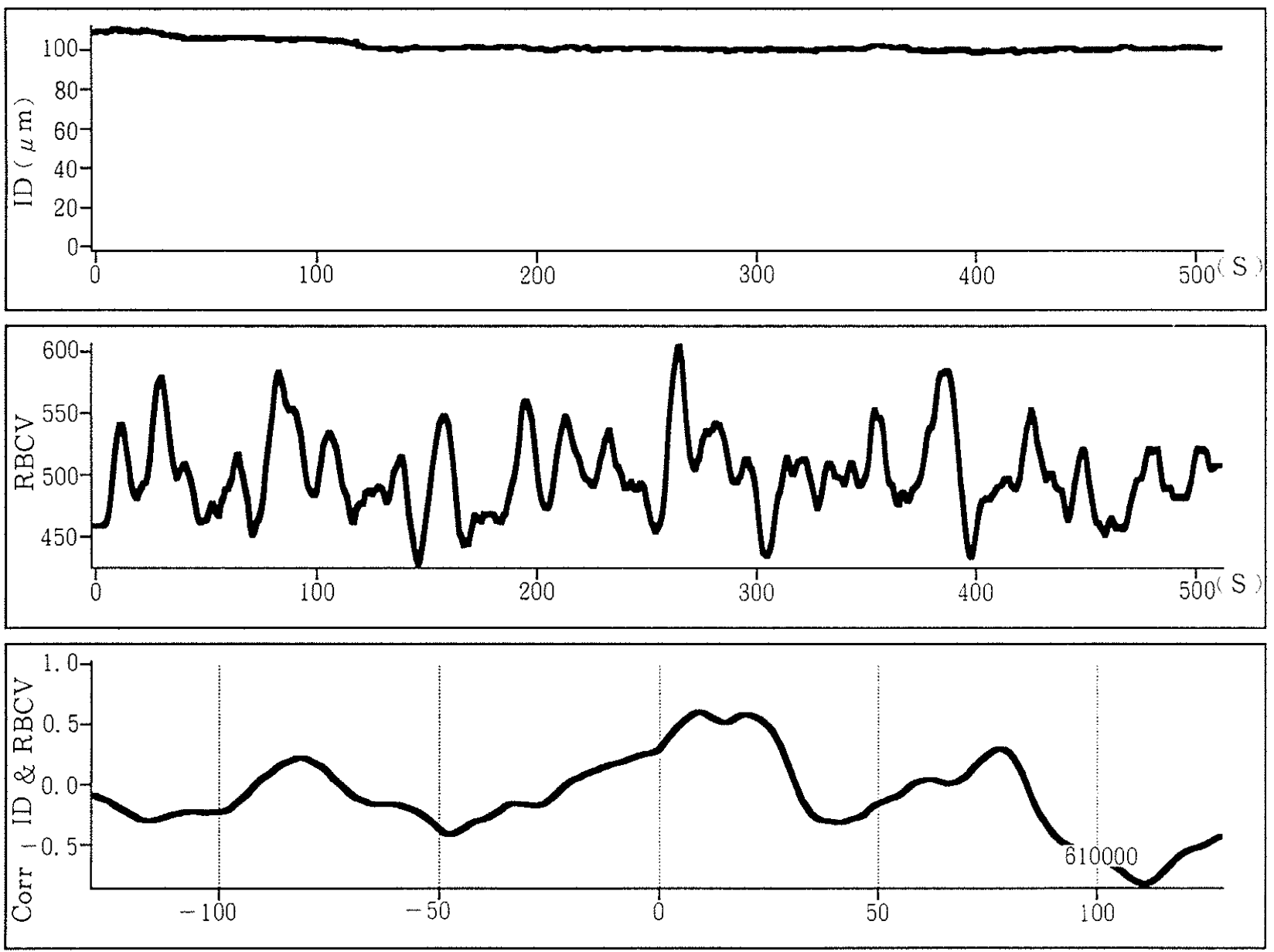

Fig. 7 A case of little change in inside diameter (ID) of an arteriole in a REC. Red blood cell velocity (RBCV) in the arteriole oscillates with a frequency of 3 cycles $/ \mathrm{min}$.

流生の増加により边管が搪張し血湤が REC内に揶し込 まれることが初めに起こるためと考えら机る。さらに，

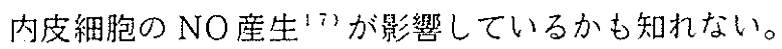

比較的高い周波数の血管運動に低い周波数のものが重 畳する例（図6）では内径と赤血球速度との間に良い相 関が認められたが，位相差は上述の例とは異なり，逆に なっていた。こ机は RBCVが ID 変化方よび REC 外 の潅流圧变化とが混在した影響を受けたためと考える。 REC 内で血管運動が分節的に出現し， REC 内での血 流は血管分枝によって位相がずれることは報告されてお $b^{(6)}$ ，ID および RBCV よの位相が揃わないことは起 こり得る。さらに，IDがほぼ一定の例でも RBCVは 相動的に変動する（図 7)ことから細動脈の血流は REC 外の血管緊張の影響を受けることが示唆される。

$\mathrm{REC}$ 内の微小血管床では細動脈, 毛細血管, 細静脈 および動静脈シャントが識別できここれらの血管では血 管運動の有無よ関わり無く位相の異なった伹流变動が兒 ら扎る。しかし，上述の振幅が大きく周波数の低い们管

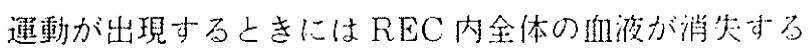

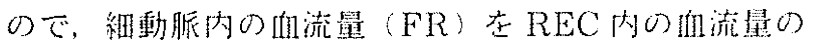

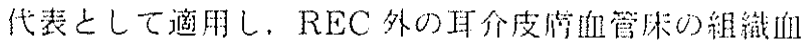
流（SBF）と比較することにした。

REC 内のFR および耳介の SBFがほぼ相なな波形 を示す（図 8 )ことや，FRが間欠的に増える上きには そのピークに一致したSBFのピークが变動波形に諗め られる(図9)ことがあった。これは血流調節が耳介全 体に影響存及焉す機構，例えば自律神経支配による血管 収䈹運動が引き起こされたためと考えられる。本来，血 管運動は筋原性であり神経支配を必須よはしない"が， REC 内に再生する微小血管は神経支配か関与して初好 て伹管運動が出現するとの報告: がが。しかし，最 近の報告2りでは REC 装着した耳介を自己移植し， 神経支配を断った REC 内でも血管運動が観察されてい る。いず扎しても，自律神経活動に起因する血管運動 を否定できない。

ヒト皮待での LDF 計测では周波数の高い血管運動に

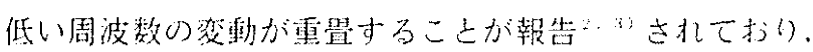

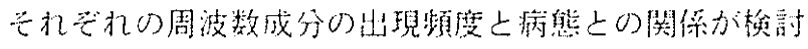

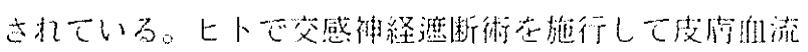

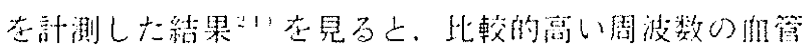



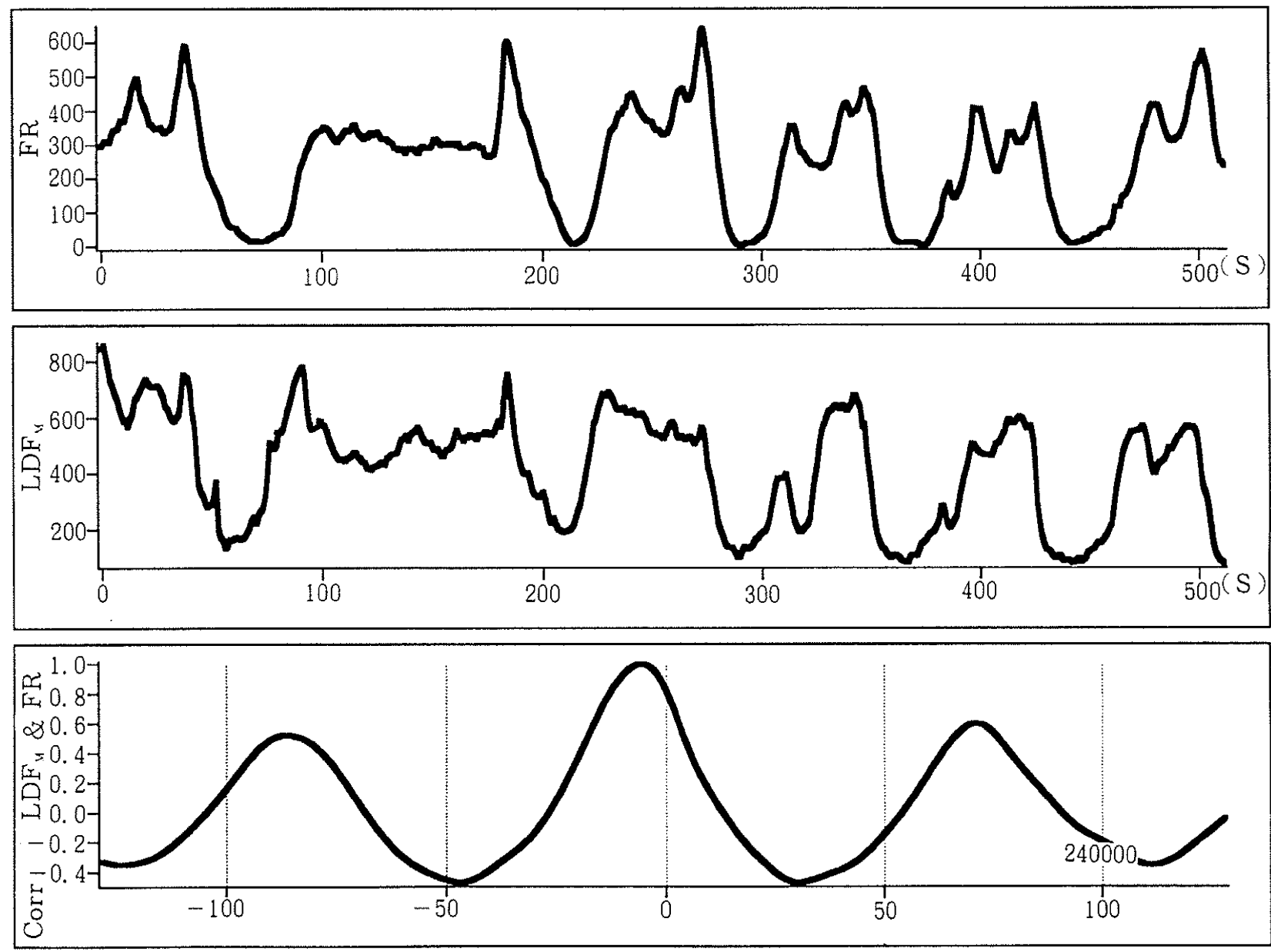

Fig. 8 Rhythmic changes in flow rate (FR) of an arteriole in a REC and skin blood flow (LDF) with a low frequency. There is a clear cross-correlation between FR and LDF.

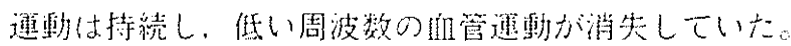
このように低い周波数の伹管運動は自律神経支配のもと で出現すると言える。

比較的高い周波数の血管運動について FR およよび SBF の変動で見る亡，両者の相互相関ではピークが時 間差ゼロ付近に認めら狆なかった（図10)。これは血管 運動が血管分岐（分節）每に独立して発現することによ り位相が揃わなかったためで，神経支配によって統合的 に欰管運動が惹起されていないことを示唆できる。実際， ヒトの皮倾でLDF 测定により高い周波数の血管運動が 観察さ扟るとき，近接した 2 箇所の血管運動は非同期的 であり，局所麻酔剤のペーストを皮府に塗ると艺の血管 運動は消失するが支配領域の神経ブロックを施行しても 血管運動には影響を及ぼさない上いう22)。さらに，皮 府に格子状の測定点を圈いて LDF 計測が行なわれた結 果23)では，血管運動が同期している場所と同期してい ない埸所が区则さ机た。こ机は血管の分岐構造扩上び向

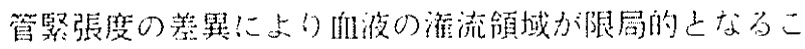
上各示戝している。

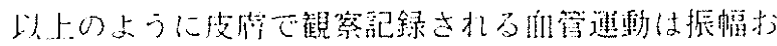

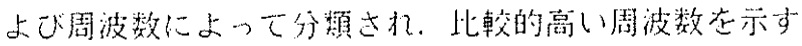
ものは伹管分節に限局しており，局所の代謝に影響され 易い可能性が示唆され，低い周波数で大きな振幅の血管 運動は耳介皮高全体支配する自律神経系の活動による と考えら扎た。本研究では REC内の細動脈のID变化 とRBCV 直接的に測定した結果をもとに耳介の LDF 計測結果とを比較し，位相差解析を応用して，上 述の血管運動の出現機序を類推することができた。

\section{5. 結 論}

1) $\mathrm{REC}$ 内の細動脈の口经変化 (vasomotion) は 小さい振幅で高い周波数のものと大きな振幅で低い周波 数のものとに分類できた。

2) REC 内で低い周波数の血管運動が観察されると きRBCVの增加が血管拡張より先行した。

3）低い周波数の血管運動が出現するとき REC 内細 動脈のFRと耳介の SBFが相似な波形を示し、雨者の 間で息い相互相関が認め的机た。

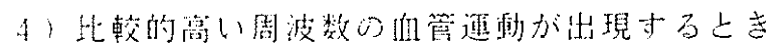

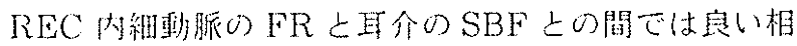



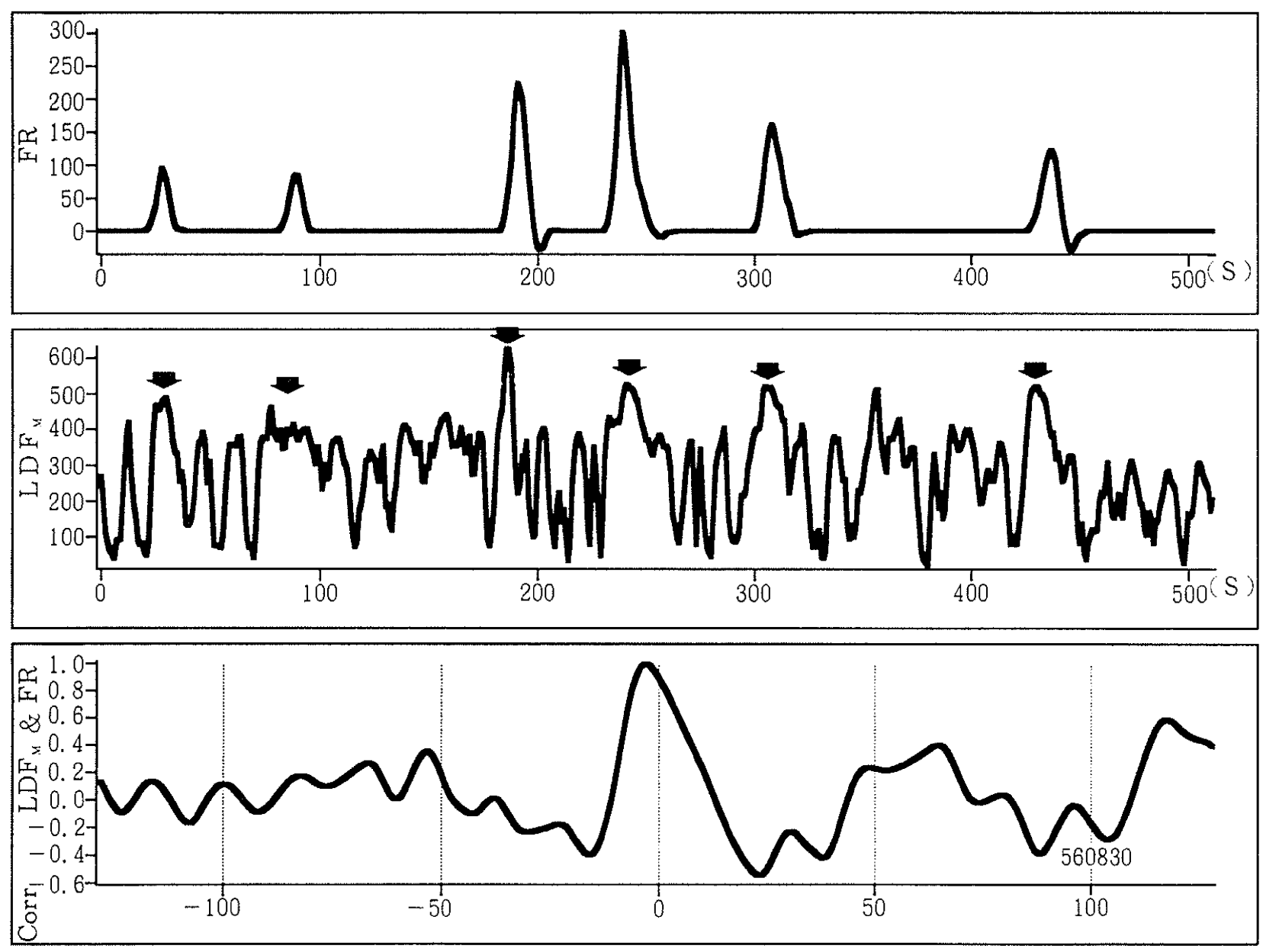

Fig. 9 Intermittent blood flow (FR) through an arteriole in a REC and rhythmic changes in skin blood flow (LDF). Peaks of FR synchronize with some peaks of LDF (arrows indicate). There is a clear cross- correlation between FR and LDF.

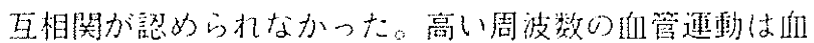
管分岐每に分節的に出現している可能性が示唆された。

5 ) REC 内の細動脈の大きな振幅で低い周波数のI D 变化は局所的な代謝因子よりも, 皮㴼組織全体の血 管を支配する自律神経活動によって莣起されることが示 唆された。

\section{6. 謝 辞}

本研究のために御指相と有意義な議論を与炎られた大 久保干代次部長（国立公摮衛生院生理衛生部）ならびに 花井荘太郎室長（国立循環器病セン夕一研究所脈管生理 部)に深く感謝いたします。

\section{文 献}

1) 南山求: 微小血管運動。日本ハイイレオロジー学 会誌，6，75-86，1992.

2) H. Seifert, K. Jaeger and A. Bollinger Analysis of flow motion by the laser Doppler technique in patients with peripheral arterial occlusive disease. Int. J. Microcirc : Clin. Exp., 7, 223-236, 1988.

3) 塚本 浩, 清野 清彦, 高野照夫, 早川弘一： 心不全症例に扰ける皮行微小循環動態の病態生理学 的研究. 脈管学, 34, $169-176,1994$.

4) Y. Seino, K. Ohki, T. Nakamura, H. Tsukamoto, T. Takano, T. Aramaki, H. Okumura, and H. Hayakawa : Pathophysiological characteristics of cutaneous microcirculation in patients with liver cirrhosis : relationships to cardiovascular hemodynamics and plasma neurohormonal factors. Microvasc. Res., 46, 206-215, 1993.

5) O. Lutolf, D. Chen. Th. Zehnder, and F. Mahler : Influence of local finger cooling on laser Doppler flux and nailfold capillary blood llow velocity in normal subjects and in pationts with Raynaud's phenomenon. 

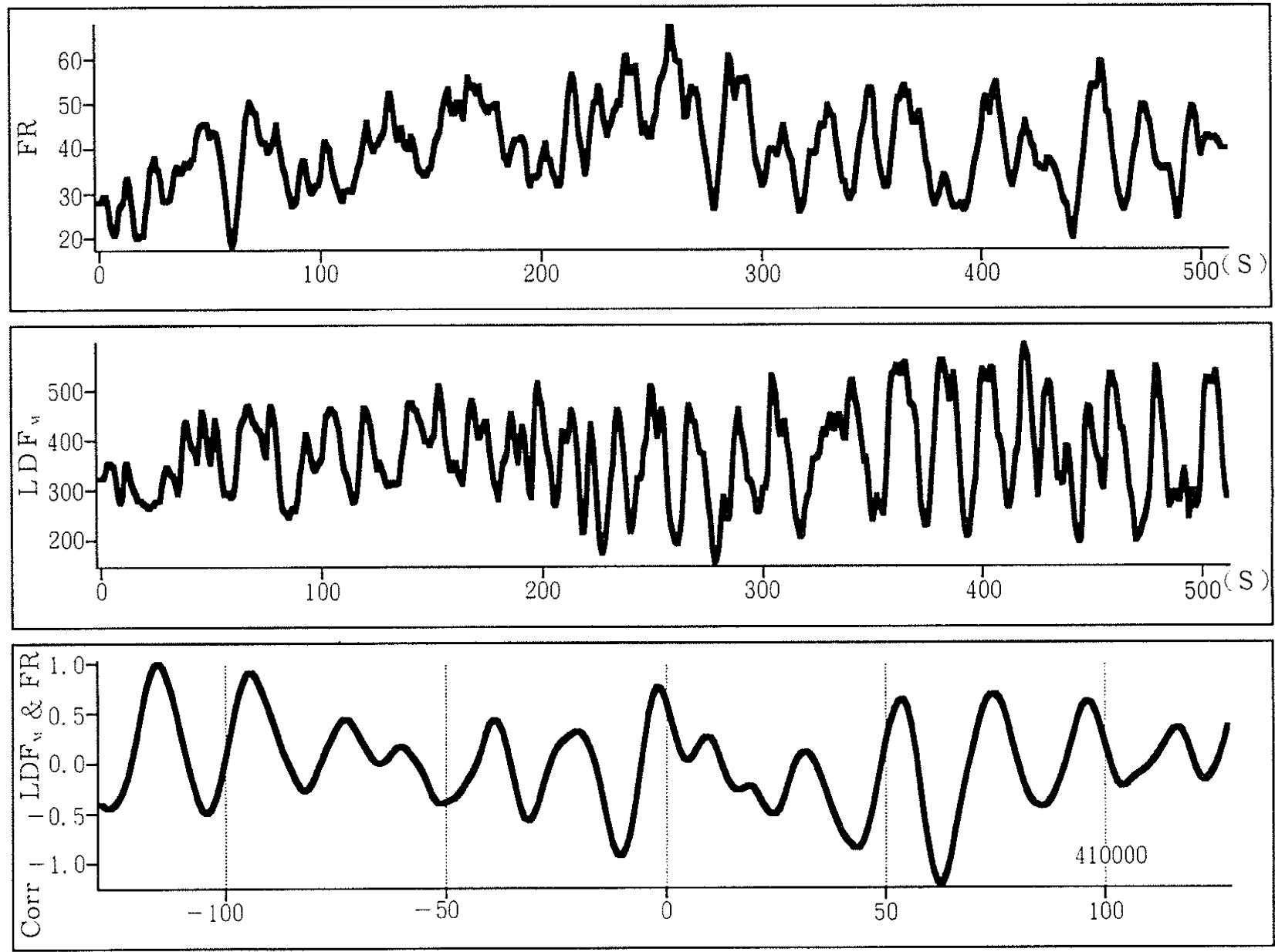

Fig. 10 Rhythmic changes in flow rate (FR) of an arteriole in a REC and skin blood flow (LDF) with a relative high frequency. There is a poor cross-correlation between $F R$ and LDF.

Microvasc, Res. 46. 374-382, 1903.

6) 鹿嶋 進, 岡 慎一朗, 石川 淳, 比企 能樹: レーザー血流測定法による組織血液量の涺定. 日本 レーザー医学会誌，12，3－9，1991。

7) N. C. Abbot and J. Swanson Beck: Biological zero in laser Doppler measurements in normal, ischaemic and inflamed human skin. Int. J. Microcirc : Clin. Exp., 12, $89-98$, 1993.

8) M. D. Stern, D. L. Lappe, P. D. Bowen, J. E. Chimosky, G. A. Holloway, Jr., H. R. K eiser, and R, L. Bowman : Continuous measurement of tissue blood flow by laser Doppler spectroscopy. Am. J. Physiol., 232, H411- H448, 1977.

$9)$ J. M. Johnson. W. F. Taylor, A. P. Shepherd. and M. K. Park : Laser-Doppler measurement of skin blood flow : comparison with plethysmography. J. Appl. Physiol.
Respirat. Environ. Exercise Physiol. 56. $789-803,1984$.

10) J. E. Tooke, J. Oestergren, and B. Fagrell : Synchronous assessment of human skin microcirculation by laser Doppler flowmetry and dynamic capillaroscopy. Int. J. Microcirc : Clin. Exp., 2, $277-284,1983$.

11）浅野牧茂，吉田敬一，田多井吉之介：Rabbit Ear Chamberによる微細循環動態の研究法について. 生体の科学, 13，285-294，1962.

12) 沢登 公勇：皮㒀微小循環におけるアドレナリン作 動性 $\alpha$ 受容体を介した細動脈管径調節ーウサギ耳空 法による検討一。公鼻衛生院研究報告，37，11-22， 1988.

13) M. Minamiyama, S. Hanai, and A. Nakano : Changes in diameter, video intensity and red blood cell velocity in rabbit ear chamber microvessels during vasomotion. Microcirc. Ann. . 8. $177-178.1092$. 
14）南山 求, 花井 荘太郎：レーザビデオディスクレ コーダおよび画像処理計测を応用した細動脈の自発 的周期的血管運動の解析. 日本バイオレオロジー学 会誌， 4，41-51，1990.

15) M. Minamiyama : The control of macroand microcirculation in the mesentery and intestine. Jpn. Cir. J., 53, $453-461.1989$.

16) M. Asano, K. Yosyida, and K. Tatai : Microphotoelectric plethysmography using a rabbit esr chamber. J. Appl. Physiol., 20, $1056-1062,1965$.

17) W. F. Jackson : Role of endothelium-derived nitric oxide vasomotion. In "Mechanoreception by the vascular wall" ed. G. M. Rubanyi, Futura, NY, pp. 173-196, 1993.

18) M. P. Weideman : Blood flow through terminal arterial vessels after denervation of the bat wing. Circ. Res., 22, $83-89,1968$.

19) E. R. Clark, E. L. Clark and R. G. Williams : Microscopic observation in the living rabbit of the new growths of nerve and the establishment of nerve controlled contractions in newly formed arterioles. Am. J. Anat., 55, 47-77, 1934.

20) J. Wadstroem and B. Gerdin : Vasomotion in the totally denervated transplanted rabbit ear chamber. Microvasc. Res., 46, 103-105, 1993.

21) J. Kastrup. J. Bulow, and N. A. Lassen : Vasomotion in human skin before and after local heating recorded with laser Doppler flowmetry. A method for induction of vasomotion. Int. J. Microcirc. : Clin. Exp., 8, $205-215$. 1989.

22) G. E. Salerud, T. Tenland, G. E. Nilsson, and $P$. A. Oeberg : Rhythmical variations in human skin blood flow. Int. J. Microcirc : Clin. Exp., 2, 91 - 102, 1983.

23) J. S. Schechner, and I. M. Braverman : Synchronous vasomotion in the human cutaneous microvasculature provides evidence for central modulation. Microvasc. Res., 44. $27-32,1992$. 